\title{
GRUNDTVIG OG TEATRET
}

\author{
Af Steen Johansen.
}

Om Grundtvig som amatørskuespiller i sin studentertid har undertegnede 2 gange skrevet i Grundtvig-Studier (1950, s. 100-102 og 1954 , s. 96 f.), og heraf var den sidste artikel nødvendiggjort som følge af nye oplysninger. Siden da er jeg atter blevet gjort opmærksom paa noget nyt, men førend jeg kommer til dette, skal jeg kort gengive de fakta, man véd om den sag.

Gr. var iflg. Jacob Steenbergs dagbog (se Gr.-St. 1950, 101) i sin studentertid medlem af et privat teaterselskab kaldt »Thalia《. Her opførtes bl. a. P. A. Heibergs »Virtuosen Nr. 2« med Gr. i rollen som Tøraf. Om tidspunktet vides intet sikkert, men Gr. digtede i sommeren 1802 »Skoleholderne《, hvori paavirkning netop fra nævnte skuespil. - Den 11. sept. 1803 opførtes Gr.s eget skuespil »Brevet« med ham selv i August Møllers rolle (se Gr.s dagbog i Udv. Skr. I, 33 f., 45). Som opførelsessted angav Gr. blot »et Privat Theater«, og formodentlig har det været Thalia. - Fra Fr. Barfod véd vi, at Gr. i »et dramatisk Selskab« spillede kusken Jochums rolle i Olufsens 》Gulddaasen« (se herom Gr.-St. 1954, 96 f.). Barfod antydede tillige, at Gr. spillede sammen med St. St. Blicher. Hvor og hvornaar skete dette? Barfods (første) hentydning til Borups Selskab (som han bag i sin bog forsigtigt ændrede til det føranførte »et dramatisk Selskab«) viste sig at være ufrugtbar. Ganske vist kunde det paavises, at nævnte selskab den 7. dec. 1803 opførte »Gulddaasen«, men Gr.s navn var ikke blandt de rollehavende. (Efter fornyet undersøgelse vides dette nu med sikkerhed). $\mathrm{Nu}$ har docent, dr. phil. Gustav Albeck elskværdigst gjort mig opmærksom paa, at vi i Gr.s dagbog for sept. 1803 finder følgende notitser:

18tende [Sept.] ... udskrev Iochums Rolle ...

22.

$24 \mathrm{de}$.

25de.
... paa Prøve ...

... var paa Prøve ...

... spilte om Aftenen Iochums Rolle

i Gulddaasen.

(Gr.-ark. fasc. 496; afskrift ved Sv. Gr. i fasc. 500.) 
Gr. har saaledes midt under eksamenslæsningen i efteraaret 1803 2 gange optraadt som amatørskuespiller, først den 11. sept. i sit eget stykke »Brevet«, antagelig i Thalia, jvf. ovenfor, saa 14 dage senere i »Gulddaasen«, rimeligvis ogsaa i Thalia ${ }^{1}$ ). Men mærkeligt nok har Begtrup kun aftrykt den forste oplysning (om »Brevet«), ikke den anden. Udfra B.s fortielse drog jeg den letsindige slutning, at der i Gr.s dagbøger $i k k e$ fandtes flere oplysninger om Gr. og teatret end denne ene, som B. gengav, hvilket altsaa var forkert.

1) Men ikke sammen med Blicher. Sejer Kühle hævder, at Bl. omkr. d. 25. sept. 1803 befandt sig paa Falster (Hist. Meddelelser om Kbh. 4. række, bd. IV, s. 594, note 21 ). 